\title{
$N, N$-Dichloro-4-methylbenzenesulphonimide as a Novel and Efficient Catalyst for Acetylation of Alcohols under Mild Conditions
}

\author{
Ardeshir Khazaei, * Amin Rostami, Zahra Tanbakochian and Zahra Zinati \\ Department of Chemistry, Faculty of Science, Bu-Ali Sina University, Hamedan, 6517838683, Iran
}

\begin{abstract}
Álcoois de estruturas diversas foram acetilados com anidrido acético, através de reações limpas e eficientes, usando-se quantidade catalítica de $N, N$-dicloro-4-metilbenzenossulfonamida em diclorometano. Todas as reações ocorreram a temperatura ambiente, com rendimentos de bons a excelentes.
\end{abstract}

Structurally diverse alcohols were acetylated in a clean and efficient reaction with acetic anhydride based on the use of a catalytic amount of $N, N$-dichloro-4-methylbenzenesulphonimide in dichloromethane. All reactions were performed at room temperature in good to excellent yields.

Keywords: $N, N$-dichloro-4-methylbenzenesulphonimide, alcohol, acetylation, acetic anhydride

\section{Introduction}

Protection of alcohols is an unavoidable exercise in organic synthesis and is frequently achieved through acetylation with anhydrides ${ }^{1}$ due to the ease of deprotection. ${ }^{1,2}$ The various catalysts developed for the activation of anhydrides include nucleophilic, ${ }^{3,4}$ and electrophilic ${ }^{5-23}$ reagents. However, these acetylation methodologies suffer from one or more disadvantages such as stringent conditions, use of hazardous materials (e.g. DMAP is highly toxic, $\mathrm{Bu}_{3} \mathrm{P}$ is flammable and air sensitive), use of costly catalysts (e.g. the triflates), load and reusability of the catalyst or in terms of yields, cumbersome methodologies. Thus, the development of a new acetylation method is in high demand.

\section{Results and Discussion}

During the course of our systematic study on application of $\mathrm{N}$-halo compounds ${ }^{24}$ in organic chemistry, we report, herein, our results on acetylation of a variety of alcohols with $\mathrm{Ac}_{2} \mathrm{O}$ using a catalytic amount of $\mathrm{N}, \mathrm{N}$-dichloro-4-methylbenzenesulphonimide (1) ${ }^{25}$ under mild reaction conditions at room temperature (Scheme 1).

* e-mail: Khazaei_1326@ @otmail.com

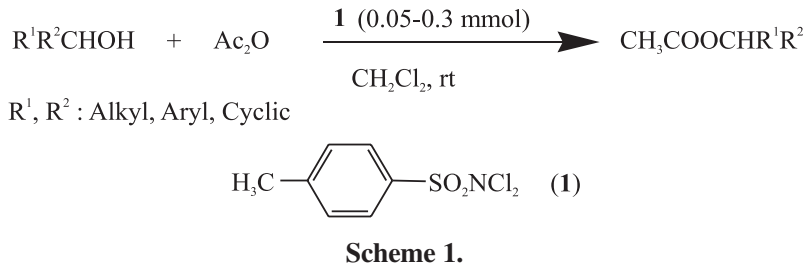

The results of the reactions of a diverse range of alcohols are collected in Table 1. The data reported in Table 1 show that, $N, N$-dichloro-4-methylbenzenesulphonimide (1) is able to promote complete acetylation of primary, secondary and tertiary alcohols in excellent yields. Primary benzylic alcohols with electron releasing and electron-withdrawing groups were acetylated in the presence of 0.05-0.2 mmol of reagent and the corresponding acetate compounds were obtained in good to excellent yields (Table 1, entries 1-4). Benzhydrol and indanol as two model compounds for secondary benzylic alcohols were satisfactorily subjected to acetylation as well (Table 1, entries 5, 6). Acetylation of linear and cyclic saturated primary and secondary alcohols was achieved in the presence of reagent $(0.05-0.1 \mathrm{mmol})$ at room temperature (Table 1, entries 7-10). Interestingly, adamantanol was also converted to the corresponding acetate at room temperature as a model for acetylation of the hindered tertiary alcohols (Table 1 , entry 11).

As shown in Table 1, the amount of the acetylating agent and catalyst depend on the nature of the alcohol used as 
Table 1. Acetylation of alcohols using $\mathrm{Ac}_{2} \mathrm{O}$ catalyzed with (1) in dichloromethane at room temperature

Substrate: $\mathrm{Ac}_{2} \mathrm{O}:(\mathbf{1})$ (Time / h; Yield /\%)

All products were characterized by comparison of their spectral data $\left({ }^{1} \mathrm{H}\right.$ NMR and IR spectroscopy) and physical properties with those of authentic samples.

substrate. Therefore we use this procedure for the selective acetylation of 4-methylbenzyl alcohol (as a model for primary alcohol) in presence of adamantanol (as a model for tertiary alcohol). The only observed product was 4-methylbenzyl acetate in 100\% conversion (Scheme 2).
Finally, a mixture of acetic anhydride and benzoic anhydride in the presence of $\mathrm{N}, \mathrm{N}$-dichloro-4-methylbenzenesulphonimide (1) was next subjected to acylation of benzyl alcohol. The acetylation of benzyl alcohol took place (100\% conversion) without any benzoylation (Scheme 3).

\section{Experimental}

Preparation of $\mathrm{N}, \mathrm{N}$-dichloro-4-methylbenzenesulphonimide (1)

4-Methylbenzenesulphonimide ( $5 \mathrm{~g}$ ) was dissolved in of saturated solution of $\mathrm{Ca}(\mathrm{ClO})_{2}(150 \mathrm{~mL})$ in a $250 \mathrm{~mL}$ flask at room temperature. After stirring for $2 \mathrm{~h}$, acetic acid $(50 \mathrm{~mL})$ was added. The resulting precipitate of $\mathrm{N}, \mathrm{N}$ dichloro-4-methylbenzenesulphonimide was filtered and washed with cold water. Recrystallization with petroleum ether afforded pure reagent in $89 \%$. mp $80{ }^{\circ} \mathrm{C}$; IR (KBr) $v_{\max } / \mathrm{cm}^{-1}: 2950(\mathrm{~s}), 1591(\mathrm{~m}), 1302(\mathrm{~m}), 1190(\mathrm{~m}), 1174(\mathrm{~s})$, 1083(m), 815(m), 761(m), 661(s), 570(s) [w:weak, m:medium, s:strong]; ${ }^{1} \mathrm{H}$ NMR $\left(\mathrm{CDCl}_{3}\right), \delta$ (ppm): 2.456 (3H, S), 7.437(2H, d), 7.868(2H, D).

General procedure for acetylation of alcohols using $\mathrm{Ac}_{2} \mathrm{O}$ and reagent 1

To a solution of alcohol $(1 \mathrm{mmol})$ and $\mathrm{Ac}_{2} \mathrm{O}(1.5-10$ mmol) in $\mathrm{CH}_{2} \mathrm{Cl}_{2}(7 \mathrm{~mL})$, catalyst $1(0.05-0.3 \mathrm{mmol})$ was added at room temperature and the mixture was stirred until complete disappearance of the starting material (alcohol). The reaction was monitored by TLC. After completion, the reaction mixture was quenched with water $(15 \mathrm{~mL})$, and extracted with $\mathrm{CH}_{2} \mathrm{Cl}_{2}(30 \mathrm{~mL})$. The solvent was evaporated, and then $n$-hexane $(20 \mathrm{~mL})$ was added to the residual solid mixture. Insoluble 4-methyl benzene sulphonimide was removed by filtration. Removal of the solvent under reduced pressure gave the product in good yield.<smiles>CC(=O)OCc1ccc(C)cc1</smiles>

Scheme 2 .

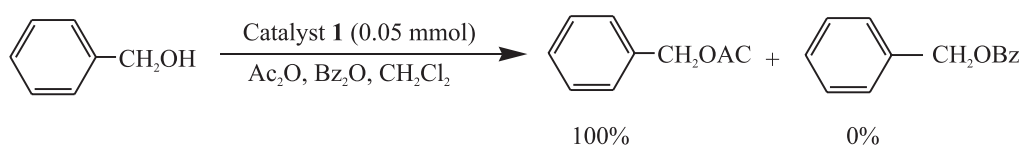

Scheme 3. 


\section{Conclusions}

In conclusion, in this study we have demonstrated the efficiency of reagent (1), towards the acetylation of a wide variety of alcohols. The notable special features of this methodology are the simple reaction procedure, selectivity, excellent yields of products, low cost reagent, easy preparation and easy work up.

\section{Acknowledgments}

We are thankful to the Bu-Ali Sina University Research Councils for partial support of this work.

\section{References}

1. Greene, T. W.; Wuts, P. G. M.; Protective Groups in Organic Synthesis, $3^{\text {rd }}$ ed., John Wiley: New York, 1999; Hanson, J. R.; Protective Groups in Organic Synthesis; Blackwell Science Inc: Malden, MA, 1999.

2. Chakraborti, A. K.; Nayak, M. K.; Sharma, L.; J. Org. Chem. 2002, 67, 1776; Chakraborti, A. K.; Nayak, M. K.; Sharma, L.; J. Org. Chem. 2002, 67, 2541; Chakraborti, A. K.; Sharma, L.; Sharma, U.; Tetrahedron 2001, 57, 9343; Chakraborti, A. K.; Nayak, M. K.; Sharma, L.; J. Org. Chem. 1999, 64, 8027.

3. Steglich, W.; Hofle, G.; Angew. Chem., Int. Ed. 1969, 8, 981.

4. Vedejs, E.; Diver, S. T.; J. Am. Chem. Soc. 1993, 115, 3358; Vedejs, E.; Bennet, N. S.; Conn, L. M.; Diver, S. T.; Gingras, M.; Lin, S.; Oliver, P. A.; Peterson, M. J.; J. Org. Chem. 1993, $58,7286$.

5. Iqbal, J.; Srivastava, R.; J. Org. Chem. 1992, 57, 2001; Ahmed, S.; Iqbal, J.; Tetrahedron Lett. 1986, 27, 3791.

6. Ishihara, K.; Kubota, M.; Kurihara, H.; Yamamoto, H.; J. Am. Chem. Soc. 1995, 117, 4413; Ishihara, K.; Kubota, M.; Kurihara, H.; Yamamoto, H.; J. Org. Chem. 1996, 61, 4560.

7. Ishihara, K.; Kubota, M.; Yamamoto, H.; Synlett 1996, 265.

8. Procopiou, P. A.; Baugh, S. P. D.; Flack, S. S.; Inglis, G. G. A.; J. Org. Chem. 1998, 63, 2342; Procopiou, P. A.; Baugh, S. P. D.; Flack, S. S.; Inglis, G. G. A.; Chem. Commun. 1996, 2625.

9. Orita, A.; Tanahashi, C.; Kakuda, A.; Otera, J.; Angew. Chem., Int. Ed. 2000, 39, 2877; Orita, A.; Tanahashi, C.; Kakuda, A.; Otera, J.; J. Org. Chem. 2001, 66, 8926; Carrigan, M. D.; Freiberg, D. A.; Smith, R. C.; Zerth, H. M.; Mohan, R. S.; Synthesis 2001, 2091.

10. Saravanan, P.; Singh, V. K.; Tetrahedron Lett. 1999, 40, 2611; Chandra, K. L.; Saravanan, P.; Singh, R. K.; Singh, V. K.; Tetrahedron 2002, 58, 1369.

11. Chandrasekhar, S.; Ramachander, T.; Takhi, M.; Tetrahedron Lett. 1998, 39, 3263.
12. Ballini, R.; Bosica, G.; Carloni, S.; Ciaralli, L.; Maggi, R.; Sartori, G.; Tetrahedron Lett. 1998, 39, 6049.

13. Bhaskar, P. M.; Loganathan, D.; Tetrahedron Lett. 1998, 39, 2215; Li, A.-X.; Li, T.-S.; Ding, T. H.; Chem. Commun. 1997, 1389.

14. Kumareswaran, R.; Pachamuthu, K.; Vankar, Y. D.; Synlett 2000, 1652.

15. Kumar, P.; Pandey, R. K.; Bodas, M. S.; Dongare, M. K.; Synlett 2001, 206.

16. Nakae, Y.; Kusaki, I.; Sato, T.; Synlett 2001, 1584.

17. Shirini, F.; Zolfigol, M. A.; Abedini, M.; Monatsh. Chem. 2004, 135, 279; Shirini, F.; Zolfigol, M.A.; Abedini, M.; Salehi P.; Bull. Korean Chem. Soc. 2003, 24, 1683; Shirini, F.; Zolfigol, M. A.; Mallakpour, B.; Int. J. Chem. Sci. 2003, 1, 53; Shirini, F.; Zolfigol, M. A.; Mohammadi, K.; Bull. Korean Chem. Soc. 2004, 25, 325; Shirini, F.; Zolfigol, M. A.; Russ. J. Org. Chem. 2005, 41, 625 .

18. Karimi, B.; Seradj, H.; Synlett 2001, 519.

19. Bartoli, G.; Bosco, M.; Dalpozzo, R.; Marcantoni, E.; Massaccesi, M.; Sambri, L.; Eur. J. Org. Chem. 2003, 4611; Bartoli, G.; Bosco, M.; Dalpozzo, R.; Massaccesi, M.; Sambri, L.; Synlett 2003, 39; Dalpozzo, R.; De Nino, A.; Maiuolo, L.; Procopio, A.; Nardi, M.; Bartoli, G.; Romeo, R.; Tetrahedron Lett. 2003, 44, 5621.

20. Salavati-Niasari, M.; Hydarzadeh, S.; Amiri, A.; Salavati, S.; J. Mol. Catal. A: Chem. 2005, 231, 191.

21. Chen, C.-T.; Kuo, J.-H.; Pawar, V. D.; Munot, Y. S.; Weng, S.-S.; Ku, C.-H.; Liu, C.-Y.; J. Org. Chem. 2005, 70, 1188.

22. Chakraborti, A. K.; Gulhane, R.; Synlett 2004, 627; Chakraborti, A. K.; Gulhane, R.; Shivani; Synlett 2003, 1805; Chakraborti, A. K.; Gulhane, R.; Shivani; Synthesis 2004, 111; Chakraborti, A. K.; Gulhane, R.; Tetrahedron Lett. 2003, 44, 3521; Chakraborti, A. K.; Gulhane, R.; Tetrahedron Lett. 2003, 44, 6749; Chakraborti, A. K.; Gulhane, R.; Sharma, L.; Shivani; Tetrahedron 2003, 59, 7661; Chakraborti, A. K.; Gulhane, R.; J. Chem. Soc., Chem. Commun. 2003, 1896.

23. Procopio, A.; Dalpozzo, R.; De Nino, A.; Maiuolo, L.; Russo, B.; Sindona, G.; Adv. Synth. Catal. 2004, 346, 1465.

24. Khazaei, A.; Vaghei, R. G.; Tetrahedron Lett. 2002, 43, 30733; Khazaei, A.; Vaghei, R. G.; Tajbakhsh, M.; Tetrahedron Lett. 2001, 42, 59; Khazaei, A.; Shirdarreh, A.; Synth. Commun. 1999, 29, 4079; Khazaei, A.; Bridson, K.; Pitchard, R. G.; Cryst. Str. Comm. C5 2001, 970; Khazaei, A.; Aminimanesh, A.; Synthesis 2004, 1739; Khazaei, A.; Zolfigol, M. A.; Rostami, A.; Synthesis 2004, 2959; Khazaei, A.; Aminimanesh, A.; Rostami, A.; J. Chem. Research 2005, 391.

25. Akiyoshi, S.; Okuno, K.; J. Am. Chem. Soc. 1954, 76, 693.

Received: July 16, 2005

Published on the web: December 15, 2005 